\title{
Analisis Kesulitan Siswa SMP Mutiara 5 Lembang pada Materi Segiempat dan Segitiga
}

\author{
Sri Rosa Aprilia ${ }^{1}$, Wahyu Setiawan ${ }^{2}$ \\ ${ }^{1,2}$ IKIP SILIWANGI, Jl. Terusan Jendral Sudirman, Cimahi Tengah, Kota Cimahi, Jawa Barat \\ rossaaprilia22@gmail.com
}

\begin{abstract}
The purpose of this study was to analyze the difficulties of students in solving problems with rectangular and triangular material. This is taken from the cognitive indicators in the bloom taxonomy which are indicators of the difficulties used in this study. The method used is descriptive qualitative method. The data collection technique is by giving questions to students. Furthermore, students' answers are analyzed to determine the extent of difficulties that have occurred to students based on the determined indicators. This research was conducted at one of the state junior high schools in Lembang for the 2020-2021 school year. The subjects were 20 grade VIII students. The instrument used was in the form of questions on the material of rectangles and triangles with predetermined indicators. The results obtained from this study were the difficulties experienced by students in the question indicators. Applying the concept of area and perimeter of the rectangle to solve the problem. This is evident from the results of the test questions to students where $70 \%$ of students experienced difficulties with the question indicators as well as the percentage of student answers that were less than the predetermined KKM. The factors that make this indicator experience difficulties are (1) Not careful in reading, understanding, and answering questions; (2) The students' lack of spatial ability to imagine rectangles and triangles; (3) Students are accustomed to working on routine questions that are included in the examples.
\end{abstract}

Keywords: Mathematics, The Covid-19 Pandemic, Online Learning

\begin{abstract}
Abstrak
Tujuan dari penelitian ini adalah untuk menganalisis kesulitan siswa dalam menyelesaikan masalah materi segiempat dan segitiga. Hal tersebut diambil dari indikator kognitif pada taksonomi bloom yang menjadi indikator kesulitan yang digunakan dalam penelitian ini. Metode yang digunakan metode deskriptif kualitatif. Teknik pengambilan datanya yaitu dengan memberikan soal kepada siswa. Selanjutnya jawaban siswa dianalisis untuk mengetahui sejauh mana kesulitan yang terjadi pada siswa berdasarkan indikator yang di tentukan. Penelitian ini dilakukan di salah satu SMP Negeri di Lembang tahun ajaran 2020-2021. Subjeknya yaitu siswa kelas VIII sebanyak 20 orang. Instrumen yang digunakan berupa soal tes materi segiempat dan segitiga dengan indikator yang telah ditentukan. Hasil yang diperoleh dari penelitian ini yaitu adanya kesulitan yang dialami siswa pada indikator soal Menerapkan konsep luas dan keliling segiempat untuk menyelesaikan masalah. Hal ini terbukti dari hasil tes soal kepada siswa dimana $70 \%$ siswa mengalami kesulitan pada indikator soal tersebut juga dilihat dari presentase jawaban siswa kurang dari KKM yang sudah ditentukan. Faktor yang membuat indikator tersebut mengalami kesulitan adalah (1) Tidak teliti dalam membaca, memahami dan menjawab soal; (2) Kurangnya kemampuan spasial siswa untuk membayangkan segiempat dan segitiga; (3) Siswa terbiasa mengerjakan soal-soal yang rutin dan terdapat pada contoh.
\end{abstract}

Kata kunci: Analisis Kesulitan, Segiempat dan Segitiga

Copyright (c) 2021 Sri Rosa Aprilia, Wahyu Setiawan

$\triangle$ Corresponding author: Sri Rosa Aprilia

Email Address: rossaaprilia22@gmail.com (Jl. Terusan Jendral Sudirman, Cimahi Tengah, Kota Cimahi, Jawa Barat) Received 16 June 2021, Accepted 25 June 2021, Published 21 July 2021

\section{PENDAHULUAN}

Salah satu mata pelajaran yang mempunyai peranan penting dalam dunia pendidikan adalah matematika. Hampir semua bidang studi melibatkan ilmu matematika. Oleh karena itu, semua orang harus mempelajari matematika agar dapat digunakan sebagai sarana untuk memecahkan masalah kehidupan sehari-hari. Dalam (Yuliati, 2021) matematika menjadi salah satu mata pelajaran yang diharapkan dapat membentuk peserta didik memiliki kemampuan dalam memecahkan masalah baik dalam persoalan matematika maupun dalam persoalan sehari-hari, sehingga matematika telah diajarkan sejak jenjang 
pendidikan sekolah dasar hingga jenjang pendidikan perguruan tinggi. Menurut Akbar et al. (2017) matematika berfungsi untuk melatih kemampuan berfikir manusia melalui pemanfaat ide-ide atau gagasan. Masih banyak siswa yang mengalami kesulitan saat memecahkan persoalan matematika, oleh karena itu guru harus lebih paham kesulitan apa saat proses pemecahan soal pembelajaran di sekolah yang dialami siswa. Sependapat dengan (Setiawan, 2015) untuk memperbaiki kualitas dalam pendidikan, para pendidik dituntut mampu mempersiapkan peserta didiknya agar memiliki berbagai kemampuan, yang nantinya mereka mampu bersaing dan berkualitas Untuk mengetahui kesulitan tersebut guru dapat memberikan pertanyaan ataupun tes mengenai materi yang sudah dipelajari.

Untuk mengetahui pemahaman materi yang diajarkan dapat dilihat ketika siswa selesai mengerjakan persoalan (Zanthy \& Fahlevi, 2020). Seperti pada materi bangun datar, siswa dituntut bisa menjelaskan definisi dengan melihat secara langsung benda tersebut tidak hanya menjelaskan keabstrakannya agar siswa mudah untuk mengerjakan persoalan tersebut. Dalam (Fitriani et al., 2018) juga berpendapat bahwa "Concepts in mathematics are abstract (including geometry). Students will have difficulty if they are emphasized to memorize" yang artinya matematika memiliki konsep yang abstrak (termasuk geometri). Dengan cara menghafal akan membuat siswa semakin kesulitan.

Yuliana \& Ratu (2019) mengemukanan bahwa geometri merupakan salah satu cabang matematika yang mempelajari ukuran, bentuk, dan posisi bentuk bangun 2 dimensi dan 3 dimensi. Geometri memiliki peluang lebih besar dari ruang lingkup yang lain untuk dipahami oleh siswa, karena geometri cocok untuk pengalaman langsung dan cara yang efektif untuk menjangkau siswa dalam mengalami kesulitan di dalam kelas. Belajar geometripun mampu memberikan pengetahuan kepada siswa karena mampu di terapkan dalam bidang lainnya yang lebih luas. Salah satu topik materi geometri yang diajarkan pada siswa kelas VII SMP/MTs adalah segiempat dan segitiga. Dengan mempelajari segiempat dan segitiga tersebut, siswa dapat lebih mudah dan cekat menyelesaikan permasalahaan di kehidupan sehari-hari yang ada kaitannya dengan konsep tersebut, seperti menghitung dan mengukurluas dan keliling pada tanah (Linda et al., 2020).

Pembelajaran segiempat dan segitiga juga sangat penting untuk dipelajari dan harus dikuasai oleh siswa SMP kelas VII (Wijaya et al., 2020), karena menjadi materi prasyarat saat siswa duduk di bangku kelas VIII berikutnya dalam mempelajari bangun ruang pada sisi datar. Dalam penelitian (Amelia et al., 2018) kesulitan siswa dalam materi tersebut adalah siswa mengalami kesulitan untuk menentukan bangun datar segitiga dengan bentuk yang berbeda namun memilik keliling yang sama. Dari hasil ulangan harian yang dikerjakan oleh siswa pada saat kegiatan Program Pengenalan Lapangan pada materi segiempat dan segitiga siswa masih mengalami kesulitan dalam menyelesaikan masalah yang melibatkan segiempat dan segitiga. Siswa tidak bisa menerapkan konsep dengan baik.

Materi segiempat dan segitiga adalah salah satu pelajaran yang dianggap sukar bagi siswa SMP (Amelia et al., 2018; Zhang et al., 2020). Siswa sering keliru dalam mengidentifikasi bentuk segi-empat dan segitiga, bahkan siswa tidak faham mengenai hubungan antara bangun segiempat. Penelitian ini pun telah dilaksanakan oleh para peneliti sebelumnya terkait dengan topik ini dan terdapat kesulitan dan kendala siswa untukmengerjakan soal-soal segiempat dan segitiga, penelitian ini dilakukan oleh Dewi (Linda et al., 
2020) mengungkapkan bahwa siswa merasa kesulitan dalam membedakan macam-macam segitiga dan segiempat, bahkan masih keliru untuk merancang strategi dan menye-lesaikan soal cerita. Khoiriyah (Sumadiasa, 2014) menyatakan hasil penelitian dilapangan banyak ditemukan bahwa nilai siswa dalam materi geometri segiempat dan segitiga masih kurang dan harus ditingkatkan. Berdasarkan hasil observasi peneliti, metode yang diberikan oleh guru di kelas lebih menekankan konsep yang mengacu pada hafalan, penggunaan rumus dalam pembelajaran konvensional yang hanya diberikan rumus tanpa tahu asal rumus tesebut yang mengakibatkan siswa mengesampingkan konsep dasar dalam materi tersebut. Hal tersebut membuat siswa hanya bisa menyelesaiakan soal menggunakan rumus yang mereka hafalkan saja, ketika diberikan soal yang berbeda dengan contoh, siswa tidak mampu menyelesaikan.

Masih banyak siswa yang sulit memahami masalah geometri, khususnya materi segiempat (Kurniawati \& Siswono, 2014). Kesulitan siswa tersebut berdampak pada hasil belajar siswa. Dilihat dari hasil observasi peneliti ketika UAS, guru menyatakan bahwa dari 3 materi yang pelajari oleh siswa kelas VII semester 2 diantaranya himpunan, garis dan sudut, segiempat dan segitiga materi segiempat dan segitia merupakan materi yang sulit untuk diselesaikan oleh siswa. Dari hal tersebut terlihat siswa megalami kesulitan dalam meyelesaiakan materi segiempat dan segitiga. Dari pernyataan-pernyataan di atas bahwa penting bagi peneliti untuk menganalisis kesulitan yang dihadapi siswa karena dengan hal tersebut dapat mengetahui faktor-faktor yang dapat mempengaruhi kesulitan siswa sehingga dapat mencari solusi penyelesaiannya. Maka, penelitian ini bertujuan untuk mendeskripsikan kesulitan siswa dalam menyelesaikan soal materi segiempat dan segitiga.

\section{METODE}

Metode Penelitian yang dilaksanakan tergolong ke dalam penelitian deskriptif kualitatif untuk mendeskripsikan analisis kesulitan siswa dalam menyelesaikan soal materi bangun ruang sisi datar. Subjek penelitian terdiri dari 20 siswa kelas VIII. Teknik pengambilan data diimplementasikan dengan cara memberikan tes soal uraian kepada siswa. Selanjutnya, jawaban siswa dikoreksi dan dianalisis. Analisis data yang dilakukan adalah reduksi data, penyajian data dan penarikan kesimpulan. Teknik pengolahan data pada tes uraian tersebut menggunakan rumus presentase yang dikemukakan oleh Arikunto (Waskitoningtyas, 2016):

$$
P=\frac{n}{N} \times 100 \%
$$

Keterangan

$\mathrm{P}=$ Presentasi jenis kesalahan

$\mathrm{n}=$ Banyak kesalahan jawaban siswa

$\mathrm{N}=$ Nilai maksimum soal 
Tabel 1. Pedoman penskoran kemampuan pemahaman matematika siswa (Sofyadin, 2019)

\begin{tabular}{|c|c|}
\hline Kategori & Skor $(\boldsymbol{\%})$ \\
\hline Sangat Baik & $86-100$ \\
\hline Baik & $76-85$ \\
\hline Cukup & $60-75$ \\
\hline Kurang & $55-59$ \\
\hline Sangat Kurang & $\leq 54$ \\
\hline
\end{tabular}

Soal-soal materi segiempat dan segitiga dalam penelitian ini telah dilakukan validasi akan keakuratannya dan cocok digunakan. Adapun salah satu soal yang diberikan kepada siswa sebagai berikut:

Sebuah Perahu layar penangkap ikan berlayar lurus ke arah Barat sejauh $30 \mathrm{~km}$ dari suatu pelabuhan, kemudian berhenti dan berhasil menangkap 1 ton ikan. Kemudian perahu layar tersebut melanjutkan berlayar lurus ke arah selatan sejauh $10 \mathrm{~km}$ untuk menangkap ikan. Setelah berhasil menangkap ikan, perahu tersebut berlayar lurus ke arah timur sejauh $30 \mathrm{~km}$. Setelah selesai menangkap ikan, kapal tersebut kembali berlayar lurus menuju pelabuhan. Dari cerita tersebut, buatlah sketsa perjalanan. Bangun datar apakah yang terbentuk dari sketsa tersebut?

Gambar 1. Contoh Soal yang diujikan

Dari soal di atas, berikut disajikan hasil table validas, realibilitas, daya pembeda dan indeks kesukarannya.

Tabel 2. Hasil Validasi Contoh Soal No 3

\begin{tabular}{|l|c|c|}
\hline \multicolumn{1}{|c|}{ Pengolahan Data } & Hasil & Interpretasi \\
\hline Validitas & 2,39 & Sangat Tinggi \\
\hline Realibilitas & 0,62 & Sedang \\
\hline Daya Pembeda & 0,45 & Kurang \\
\hline Indeks Kesukaran & 0,51 & Sedang \\
\hline
\end{tabular}

\section{HASIL DAN DISKUSI}

Instrumen Penelitian ini mengukur hasil jawaban siswa berdasarkan indikator materi segiempat dan segitiga yaitu menyelesaikan masalah yang berkaitan dengan luas dan keliling segiempat, menyelesaikan masalah dalam kehidupan sehari-hari yang berkaitan dengan luas dan keliling segiempat, menyelelesaikan soal penerapan bangun datar segiempat, menerapkan konsep luas dan keliling segiempat dan segitiga untuk menyelesaikan masalah, menyelesaikan soal penerapan bangun datar segitiga. Data penelitian ini diambil dari 20 siswa kelas VIII dengan memberikan 5 butir test soal uraian. Penelitian ini dilaksanakan Jum'at, 26 Februari 2021. Sebelum diketahui kesulitan siswa terhadap masing-masing butir soal, adapun hasil tes uji kesalahan soal disajikan pada Tabel 2.

Tabel 3. Hasil Uji Tes Soal

\begin{tabular}{|c|l|c|}
\hline $\begin{array}{c}\text { No Butir } \\
\text { Soal }\end{array}$ & \multicolumn{1}{|c|}{ Indikator Soal } & $\begin{array}{c}\text { Presentase } \\
\text { Jawaban Siswa }\end{array}$ \\
\hline 1 & $\begin{array}{l}\text { Menyelesaikan masalah yang berkaitan dengan luas dan } \\
\text { keliling segiempat }\end{array}$ & $80 \%$ \\
\hline 2 & Menyelelesaikan soal penerapan bangun datar segitiga & $60 \%$ \\
\hline 3 & Menyelelesaikan soal penerapan bangun datar segiempat & $65 \%$ \\
\hline
\end{tabular}




\begin{tabular}{|c|l|c|}
\hline 4 & $\begin{array}{l}\text { Menyelesaikan masalah dalam kehidupan sehari-hari yang } \\
\text { berkaitan dengan luas dan keliling segiempat }\end{array}$ & $55 \%$ \\
\hline 5 & $\begin{array}{l}\text { Menerapkan konsep luas dan keliling segiempat untuk } \\
\text { menyelesaikan masalah }\end{array}$ & $30 \%$ \\
\hline
\end{tabular}

Berdasarkan hasil uji coba soal, dapat dilihat dari analisis data pada tabel 2 dalam butir soal ke satu dengan indikator tersebut, hasil nilai presentase yang di dapat dari seluruh siswa mencapai $80 \%$ tergolong kategori soal yang mudah. Pada butir soal ke 2 hasil nilai presentase yang di peroleh dari semua siswa mencapai $60 \%$ tergolong kategori cukup. Pada butir soal ke 3 hasil nilai presentase yang di peroleh dari semua siswa mencapai $65 \%$ tergolong kategori cukup. Pada butir soal ke 4 hasil nilai presentase yang di peroleh dari seluruh siswa mencapai 55\% tergolong kategori kurang. Pada butir soal ke 5 hasil nilai presentase yang di dapat dari seluruh siswa mencapai 30\% tergolong kategori sangat kurang. Hal ini menetapkan bahwa siswa kesulitan dalam menjawab soal ke 5 dengan indikator menerapkan konsep luas dan keliling segiempat untuk menyelesaikan masalah. Salah satu hasil jawaban siswa pada butir soal ke 1 . Halaman rumah Pak Tedi berbentuk persegi dengan ukuran sisinya 60 meter. Pak Tedi akan memasang pagar disekeliling halaman itu
Jengan biaya pagar Rp. 100.000 ,- per meter. Tentukan biaya yang diperlukan untuk pemasangan pagar tersebut!

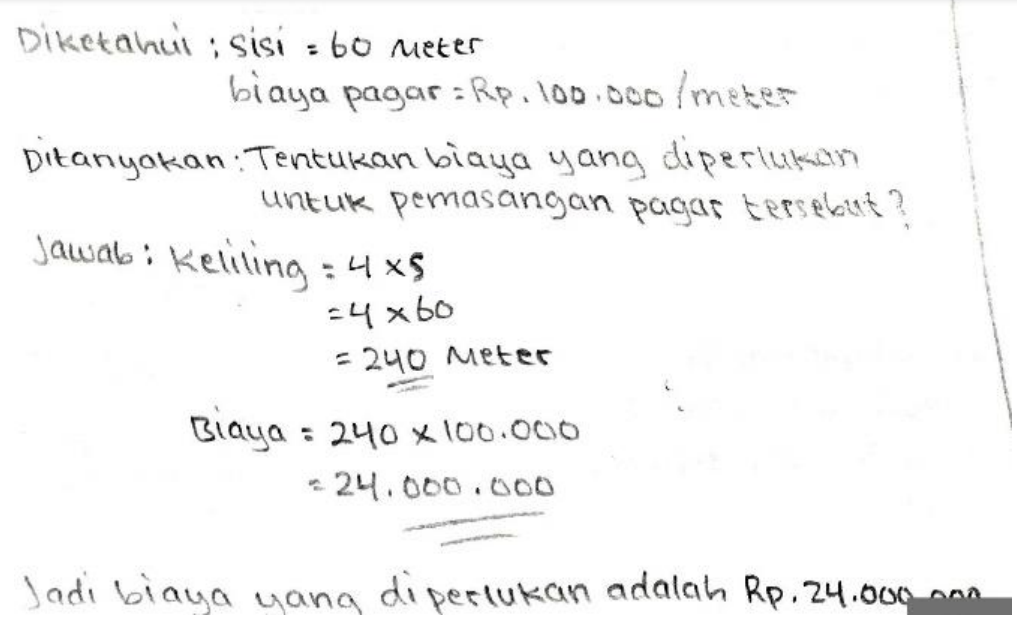

Gambar 1. Hasil Siswa Butir Soal 1

Dari gambar 1 terlihat bahwa siswa sudah mampu memahami konsep dengan baik karena jawaban nya sudah benar dan sangat jelas. Siwa dapat menyelesaikan permasalahn di atas dengan sangat baik dan jelas. Jawaban siswa sudah terperinci mulai dari model matematika diketahui, ditanyakan dan dijawab sudah sistematis. Salah satu hasil jawaban siswa pada butir soal ke 2 .

Pada gambar 2, siswa disini sudah mengerjakan dengan baik dan benar. Hanya saja, siswa tidak mencantumkan data yang diketahui pada soal tersebut. Maka, penyelesaian soal ini sudah benar tapi tidak sistematis. Sejalan dengan penelitian (Syadiah et al., 2020) siswa tidak menuliskan apa yang diketahui dan apa yang ditanyakan pada jawabannya, sedangkan hal tersebut penting dalam proses pengerjaan soal matematika. Faktor penyebabnya adalah kurangnya siswa dalam latihan soal tentang materi segitiga dan segiempat. 
'erbandingan sudut-sudut dalam segtitiga adalah $3: 5: 7$. Coba kamu tentukan sudut yang terbesar dari segitiga tersebut!

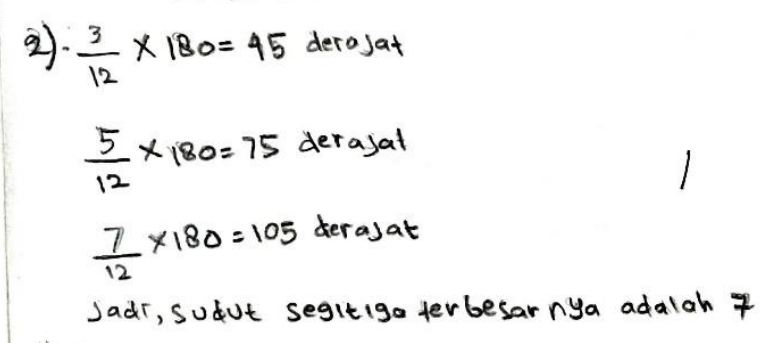

Gambar 2. Hasil Jawaban Siswa Butir Soal 2

Salah satu hasil jawaban siswa pada butir soal ke 3 .

Sebuah Perahu layar penangkap ikan berlayar lurus ke arah Barat sejauh $30 \mathrm{~km}$ dari suatu pelabuhan, kemudian berhenti dan berhasil menangkap 1 ton ikan. Kemudian perahu layar tersebut melanjutkan berlayar lurus ke arah selatan sejauh $10 \mathrm{~km}$ untuk menangkap ikan. Setelah berhasil menangkap ikan, perahu tersebut berlayar lurus ke arah timur sejauh $30 \mathrm{~km}$. Setelah selesai menangkap ikan, kapal tersebut kembali berlayar lurus menuju pelabuhan. Dari cerita tersebut, buatlah sketsa perjalanan. Bangun datar apakah yang terbentuk dari sketsa tersebut?

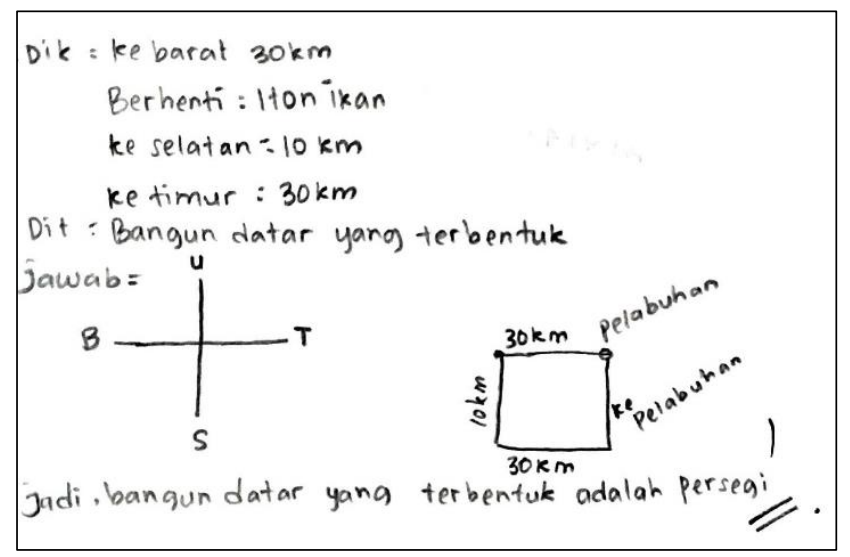

Gambar 3. Hasil Jawaban Siswa Butir Soal 3

Dilihat dari gambar ke 3, kesulitan siswa dalam mengerjakan soal ke 3 yaitu siswa tidak bisa mengidentifikasi data yang diketahui dan tidak mengaitkan satu konsep ke konsep lainnya. Hal inipun sejalan dengan hasil penelitian (Aliah \& Bernard, 2020) siswa keliru menentukan rencana penyelesaian masalah juga siswa kebingungan untuk menentukan strategi penyelesaian masalah. Dari hasil jawaban diatas siswa bingung dalam menentukan konsep matematika untuk volume balok. Salah satu hasil jawaban siswa pada butir soal ke 4.

Berdasarkan Gambar ke 4, hasil yang di dapat siswa saat mengerjakan soal ke 4 yaitu siswa sudah terampil menyelesaikan soal tentang menghitung luas permukaan kubus dan balok, hanya saja siswa belum bisa mengaitkan satu konsep ke konsep yang lain. Sukmawati \& Amelia Risma (2020) menyatakan bahwa siswa belum memahami konsep bangun datar segiempat. Hal ini mengakibatkan siswa pemahaman siswa terhadap konsep segiempat dan segitiga kurang. 

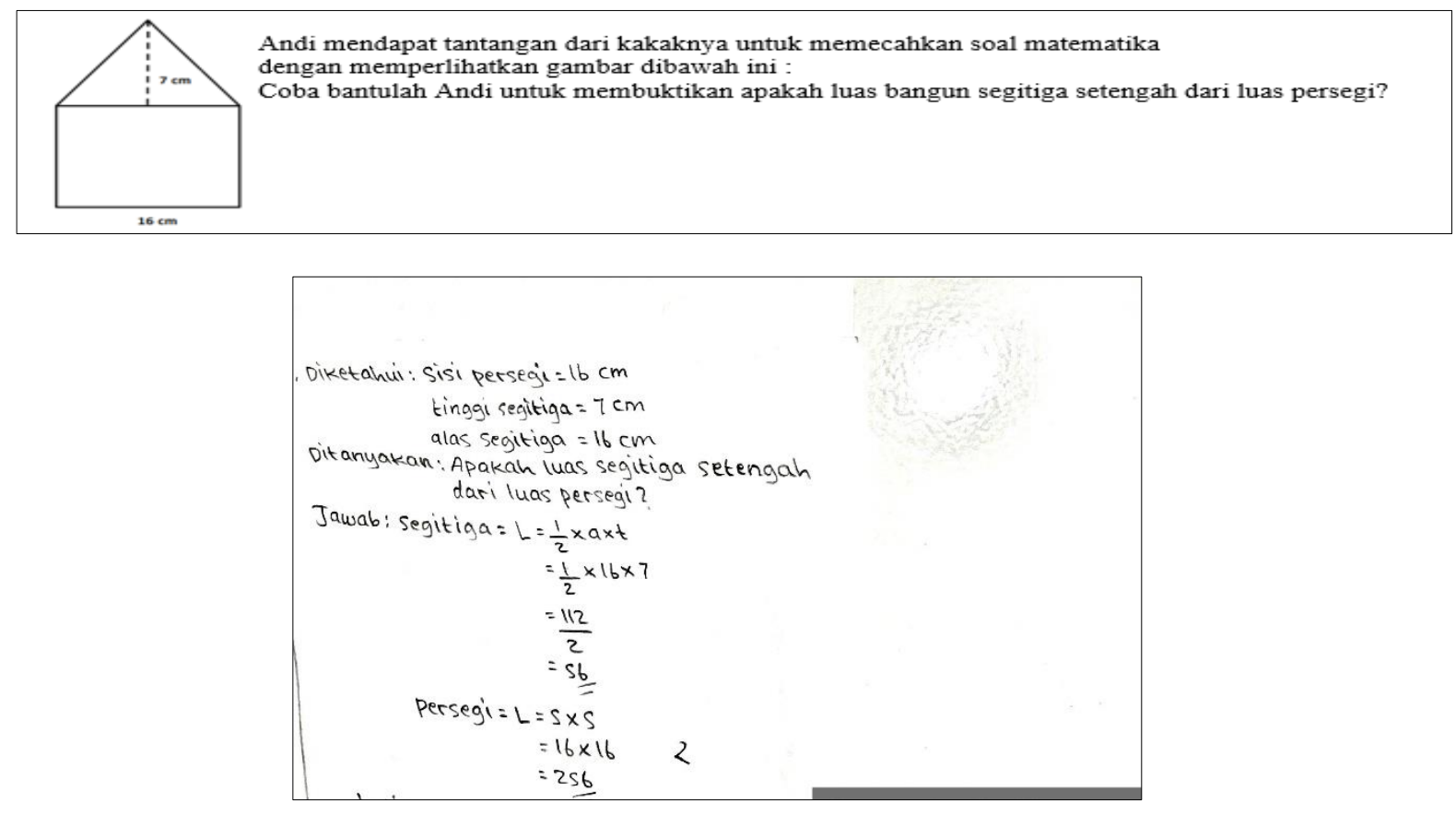

Gambar 4. Hasil Jawaban Siswa Butir Soal 4

Salah satu hasil jawaban siswa pada butir soal ke 5 .

Diketahui sebuah persegi panjang memiliki panjang $(x+4) \mathrm{cm}$ dan lebar $5 \mathrm{~cm}$. luas persegi panjang tersbut $60 \mathrm{~cm}^{2}$. Dapatkah kamu menentukan keliling dari persegi panjang tersebut? Konsep apa yang kamu kaitkan untuk menjawab persoalan tersebut?

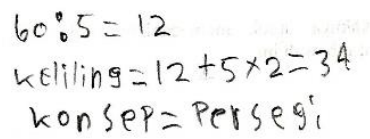

\section{Gambar 5. Hasil Jawaban Siswa Butir Soal 5}

Berdasarkan Gambar ke 5, terlihat bahwa siswa hanya menuliskan apa yang diketahui dan ditanyakan pada soal tersebut. Karena kurangnya pemahaman siswa dalam mengaitkan suatu konsep atau prinsip yang ada. Dalam hal ini terlihat jelas siswa masih merasa bingung dengan rumus-rumus yang ada pada materi segitiga dan segiempat sehingga antara rumus satu dengan rumus yang lainnya tertukar. Sependapat dengan (Wijayanto et al., 2018) kesulitan dalam menjawab soal karena siswa tidak hafal rumus, kesulitan dalam menafsirkan solusi karena tidak memperhatikan apa yang ditanyakan dalam soal, dan pemahaman siswa tentang soal yang diberikan masih rendah.

Hasil dari penelitian didapat bahwa siswa kelas IX di SMP Mutiara 5 Lembang masih banyak siswa yang kesulitan saat memecahkan soal uraian mengenai materi segiempat dan segitiga. Dilihat dari jawaban tes siswa, siswa mengalami kesulitan mengerjakan soal pada butir soal ke 5 dengan indikator soal menerapkan konsep luas dan keliling segiempat untuk menyelesaikan masalah. Hal ini didukung oleh penelitian (Sumiati \& Agustini, 2020) yang mengungapkan bahwa kesulitan yang dialami siswa SMP kelas VII pada materi segiempat dan segitiga adalah menerapkan konsep luas dan keliling segiempat dan segitiga dalam menyelesaikan masalah. Sependapat dengan Linda, Bernard \& Fitriani (2020) bahwa siswa kesulitan 
dalam memecahkan soal mencari luas dan keliling segitiga. Permasalahan yang muncul dalam konsep keliling dan luas segitiga dan segiempat adalah penerapan konsep pada soal cerita yaitu sulitnya pemahaman terhadap soal (Wardhani et al., 2019).

Kesulitan menerapkan konsep luas dan keliling segiempat dan segitiga dikemukakan juga oleh (Putra et al., 2020) dalam penelitiannya bahwa kesalahan yang paling banyak dialami oleh siswa dalam materi bangun datar segiempat dan segitiga adalah siswa masih kebingungan dalam mengimplementsikan konsep segiempat dan segitiga dalam menyelesaikan masalah. Kesulitan indikator tersebut terjadi karena siswa belum mampu menghubungkan satu konsep dengan konsep dengan konsep yang lainnya. Dilihat dari hasil jawaban siswa, siswa hanya menuliskan isi yang diketahui dan ditanyakan dalam soal tersebut tanpa menyelesaikannya. Hal tersebut karena pemahaman siswa ketika diberikan soal yang harus mensketsakan bentuk segiempat dan segitiga itu masih kurang. Sejalan dengan temuan (Indraswari et al., 2019) yang menunjukan bahwa siswa sulit membuat sketsa atau mengkontruksi model bangun datar segiempat dan segitiga. Menurut subjek, permasalahan yang diberikan adalah materi yang sulit hal ini sesuai dengan pandangan (Badraeni et al., 2020) bahwa siswa tidak memahami soal dan konsep, juga masih banyak siswa yang kebingungan pada saat menyelesaikan permasalahan dan mengidentifikasi soal karena menurut siswa pertanyaan yang diajukan sulit.

Oleh karena itu, pada umumnya hal-hal yang menyebabkan siswa melakukan kesalahan dalam menyelesaikan materi segiempat dan segitiga adalah sebagai berikut:

1. Tidak teliti dalam membaca, memahami dan menjawab soal.

2. Kurangnya kemampuan spasial siswa untuk membayangkan segiempat dan segitiga.

3. Siswa terbiasa mengerjakan soal-soal yang rutin dan terdapat pada contoh.

Hal ini sejalan dengan pandangan yang dikemukakan dalam (Sumiati \& Agustini, 2020) yang mengatakan bahwa masalah yang terjadi pada siswa adalah kurangnya ketelitian dalam memahami soal, dalam memahami masalah, dan lupa rumus-rumus. (Sulistiawati, 2014) juga mengungkapkan bahwa sebagian besar kesalahan siswa ada pada menentukan langkah-langkah pengerjaan, hal ini dikarenakan siswa tidak membiasaan dirinya dalam mengerjakan soal-soal. Pernyataan di atas pun diperkuat oleh (Bariyyah \& Amelia, 2020) bahwa penyebab kesulitan belajar dalam menyelesaikan soal materi segiempat dan segitiga adalah siswa kurang memahami materi khususnya bangun ruang, tidak memperhatikan ketika belajar, kurang latihan soal, kurang pemahaman mengenai konsep dasar bangun ruang dan pemahaman untuk konsep lainnya.

Dengan adanya penelitian ini diharapkan pendidik mampu membimbing dan mengatasi kesulitan yang dialami siswanya. Sehingga siswa mampu meningkatkan hasil belajarnya dalam pelajaran matematika terutama dalam materi segiempat dan segitiga. (Junitasari et al., 2021) menyatakan bahwa guru bukan hanya bertugas untuk membantu kesulitan siswanya saja tetapi guru juga harus mampu mengembangkan sikap positif pada diri siswanya terhadap pembelajaran matematika. (Hendriana, 2012) juga mengatakan bahwa guru juga berperan agar membuat siswa menyenangi pelajaran matematika. 


\section{KESIMPULAN}

Berdasarkan hasil pembahasan di atas dapat disimpulkan bahwa hasil yang diperoleh dari penelitian ini adalah siswa mengalami kesulitan pada indikator soal menerapkan konsep luas dan keliling segiempat untuk menyelesaikan masalah. Hal tersebut dibuktikan dengan hasil jawaban siswa yang mencapai $70 \%$ mengalami kesulitan pada indikator soal tersebut juga dilihat dari presentase jawaban siswa berada di bawah KKM. Faktor yang membuat indikator tersebut mengalami kesulitan adalah (1) Tidak teliti dalam membaca, memahami dan menjawab soal; (2) Kurangnya kemampuan spasial siswa untuk membayangkan segiempat dan segitiga; (3) Siswa terbiasa mengerjakan soal-soal yang rutin dan terdapat pada contoh.

\section{UCAPAN TERIMAKASIH}

Ucapan Terima kasih kepada Kepala Sekolah yang sudah menerima dan memperbolehkan peneliti untuk mengadakan penelitian. Terima kasih kepada guru mata pelajaran yang sudah membimbing dan mengarahkan, juga kepada siswa yang sudah mengikuti pembelajaran dengan baik.

\section{REFERENSI}

Akbar, P., Hamid, A., Bernard, M., \& Sugandi, A. I. (2017). Analisis Kemampuan Pemecahan Masalah Dan Disposisi Matematik Siswa Kelas Xi Sma Putra Juang Dalam Materi Peluang. Jurnal Cendekia : Jurnal Pendidikan Matematika, 2(1), 144-153. https://doi.org/10.31004/cendekia.v2i1.62

Aliah, S. N., \& Bernard, M. (2020). Analisis kesulitan siswa dalam menyelesaikan soal pemecahan masalah berbentuk cerita pada materi segitiga dan segiempat. Suska Journal of Mathematics Education, 6(2), $111-118$.

Amelia, R., Aripin, U., \& Hidayani, N. (2018). Analisis Kemampuan Berpikir Kreatif Matematik Siswa Smp Pada Materi Segitiga Dan Segiempat. JPMI (Jurnal Pembelajaran Matematika Inovatif), 1(6), 1143. https://doi.org/10.22460/jpmi.v1i6.p1143-1154

Badraeni, N., Pamungkas, R. A., Hidayat, W., Rohaeti, E. E., \& Wijaya, T. T. (2020). Analisis Kesulitan Siswa Berdasarkan Kemampuan Pemahaman Matematik Dalam Mengerjakan Soal Pada Materi Bangun Ruang Sisi Datar. Jurnal Cendekia: Jurnal Pendidikan Matematika, 4(1), 247-253. https://doi.org/10.31004/cendekia.v4i1.195

Bariyyah, K., \& Amelia, R. (2020). Analisis Kesalahan dalam Menyelesaikan Soal Bangun Ruang Sisi Datar pada Siswa Kelas IX SMP di Kota Cimahi 1,2. Jurnal Pembelajaran Matematika Inovatif, 3(5), 403-414. https://doi.org/10.22460/jpmi.v3i5.403-414

Fitriani, N., Suryadi, D., \& Darhim, D. (2018). the Students' Mathematical Abstraction Ability Through Realistic Mathematics Education With Vba-Microsoft Excel. Infinity Journal, 7(2), 123. https://doi.org/10.22460/infinity.v7i2.p123-132

Hendriana, H. (2012). Pembelajaran Matematika Humanis Dengan Metaphorical Thinking Untuk Meningkatkan Kepercayaan Diri Siswa. Infinity Journal, $1(1), \quad 90$. https://doi.org/10.22460/infinity.v1i1.9

Indraswari, L., Lestari, A. W., \& Hastari, R. C. (2019). Analisis Kesulitan Siswa Dalam Menyelesaikan Soal-Soal Hots Materi Segiempat Dan Segitiga Ditinjau Dari Gender. Delta: Jurnal Ilmiah Pendidikan Matematika, 7(2), 65. https://doi.org/10.31941/delta.v7i2.874

Junitasari, J., Roza, Y., \& Yuanita, P. (2021). Pengembangan Perangkat Pembelajaran Matematika Berbasis Model Core untuk Memfasilitasi Kemampuan Pemecahan Masalah Matematis Peserta Didik SMP. 
Jurnal Cendekia: Jurnal Pendidikan Matematika, 5(1), 744-758. https://doi.org/10.31004/cendekia.v5i1.415

Kurniawati, A. D., \& Siswono, T. Y. E. (2014). Pengaruh Kecemasan dan Self Efficacy Siswa terhadap Kemampuan Pemecahan Masalah Materi Segiempat Siswa Kelas VII MTs Negeri Ponorogo. MATHEdunesa, Jurnal Ilmiah Pendidikan Matematika, 3(2), 36-41.

Linda, Bernard, M., \& Fitriani, N. (2020). Analisis Kesulitan Siswa SMP Kelas VIII pada Materi Segiempat dan Segitiga Berdasarkan Tahapan Berpikir Van Hiele terlepas dari kehidupan manusia . ilmu yang wajib dipelajari oleh setiap orang . Mempelajari ilmu pada bidang mengembangkan pola pikir ( mind. $4(2), 233-242$.

Putra, A. A., Jaeng, M., \& Sukayasa, S. (2020). Analisis Kesalahan Siswa Kelas VII SMP Al-Azhar Mandiri Palu dalam Menyelesaikan Soal Cerita pada Materi Luas dan Keliling Bangun Datar. Jurnal Elektronik Pembelajaran Matematika, 3(3), 303-316.

Setiawan, W. (2015). Meningkatkan Kemampuan Berpikir Kritis Matematis Siswa Smp Dengan Menggunakan Model Penemuan Terbimbing. P2M STKIP Siliwangi, 2(1), 91. https://doi.org/10.22460/p2m.v2i1p91-97.168

Sofyadin, R. T. (2019). Implementation The Problem Based Learning Models To Improve Learning Outcomes Of XI Iis 1 Class 2 State High School Students Baubau Southeast Sulawesi. La Geografia, $17(3)$.

Sukmawati, S., \& Amelia Risma. (2020). Analisis Kesalahan Siswa SMP dalam Menyelesaikan Soal Materi Segiempat Berdasarkan Teori Nolting. jurnal Pembelajaran Matematika Inovatif, 3(2), 223. https://doi.org/10.22460/jpmi.v3i5.423-432

Sulistiawati. (2014). Analisis Kesulitan Belajar Kemampuan Penalaran matematis Siswa SMP pada Materi Luas Permukaan dan Volume Limas. Seminar Nasional Pendidikan Matematika, November, 89-95. semnas.fkip.umpo.ac.id

Sumadiasa, I. G. (2014). Analisis Kesalahan Siswa Kelas VIII SMP Negeri 5 Dolo dalam Menyelesaikan Soal Luas Permukaan dan Volume Limas. Jurnal Elektronik Pendidikan Matematika Tadulako, O1(2), 184-207.

Sumiati, A., \& Agustini, Y. (2020). Analisis Kesulitan Menyelesaikan Soal Segiempat dan Segitiga Siswa SMP Kelas VIII di Cianjur. Jurnal Cendekia : Jurnal Pendidikan Matematika, 04(01), 321-330.

Syadiah, S., Yulianti, Y., \& Zanthy, L. S. (2020). Analisis Kesalahan Siswa Smp Kelas Viii Dalam Menyelesaikan Soal Segitiga Dan Segi Empat. Teorema: Teori dan Riset Matematika, 5(2), 263. https://doi.org/10.25157/teorema.v5i2.3070

Wardhani, D., Subanji, S., \& Qohar, A. (2019). Penalaran Analogi Siswa Dalam Menyelesaikan Masalah Luas Dan Keliling Segitiga Dan Segiempat. Jurnal Pendidikan - Teori, Penelitian, dan Pengembangan, 1(9), 1764-1773. https://doi.org/10.17977/jp.v1i9.6771

Waskitoningtyas, R. S. (2016). Analisis Kesulitan Belajar Matematika Siswa Kelas V Sekolah Dasar Kota Balikpapan Pada Materi Satuan Waktu Tahun Ajaran 2015/2016. JIPM (Jurnal Ilmiah Pendidikan Matematika), 5(1), 24. https://doi.org/10.25273/jipm.v5i1.852

Wijaya, T. T., Sukma, M., Purnama, A., \& Tanuwijaya, H. (2020). Pengembangan media pembelajaran berbasis tpack menggunakan hawgent dynamic mathematics software. Journal of Elementary Education, 03(03), 64-72.

Wijayanto, A. D., Fajriah, S. N., \& Anita, I. W. (2018). Analisis Kemampuan Komunikasi Matematis Siswa Smp Pada Materi Segitiga Dan Segiempat. Jurnal Cendekia: Jurnal Pendidikan Matematika, 2(1), 97-104. https://doi.org/10.31004/cendekia.v2i1.36 
Yuliana, D., \& Ratu, N. (2019). Analisis Keterampilan Dasar Visual Geometri Siswa SMP Ditinjau Berdasarkan Level Berpikir Analisis Van Hiele. Jurnal Cendekia: Jurnal Pendidikan Matematika, 3(2), 536-549. https://doi.org/10.31004/cendekia.v3i2.135

Yuliati, I. (2021). Kemampuan Pemecahan Masalah Matematika Ditinjau Dari Minat Belajar Peserta Didik. Jurnal Cendekia: Jurnal Pendidikan Matematika, 05(02), 1159-1168.

Zanthy, L. S., \& Fahlevi, M. syahreza. (2020). Analisis Kesulitan Siswa Dalam Menyelesaikan Soal Uraian Pada Materi Bangun Ruang Sisi Datar. JPMI (Jurnal Pembelajaran Matematika Inovatif), 3(4), 313 322. https://doi.org/10.22202/j1.2020.v6i2.3379

Zhang, L., Zhou, Y., \& Wijaya, T. T. (2020). Hawgent dynamic mathematics software to improve problemsolving ability in teaching triangles. Journal of Physics: Conference Series, 1663(1). https://doi.org/10.1088/1742-6596/1663/1/012069. 